\title{
SGMS1 wt Allele
}

National Cancer Institute

\section{Source}

National Cancer Institute. SGMS1 wt Allele. NCI Thesaurus. Code C105017.

Human SGMS1 wild-type allele is located in the vicinity of 10q11.2 and is approximately

$319 \mathrm{~kb}$ in length. This allele, which encodes phosphatidylcholine:ceramide

cholinephosphotransferase 1 protein, is involved in the mediation of apoptosis. 